\title{
LABOUR LAW PATRIMONIAL LIABILITIES. GENERAL ASPECTS
}

Georgiana COVRIG, Assistant lecturer, $\mathrm{PhD}$ candidate Faculty of Law and Public Administration, Constanta Spiru Haret University georgiana.covrig@spiruharet.ro

\begin{abstract}
The damages under labour law are assessed according to special legal provisions and in the absence of such regulations, civil law regulations must be applied in relation to the prices at the time at which the agreement of will was made or the damaged person may bring the action before the court. In the case of goods' damage, the damage assessment is done in all cases taking into account the real degree of wear of the asset.
\end{abstract}

Keywords: legal liabilities, civil contractual liability principles

JEL Classification: $\mathrm{K}_{31}, \mathrm{~K}_{39}$

\section{Introduction}

In terms of legal language, the term "liability" has acquired a special significance in relation to the ordinary language, namely: it highlights the negative consequences occurred in committing illegal acts by a natural person or a legal person. According to the Labour Code (Law no. 53/2003, The Labour Code, amended and republished in 2011), employees are responsible from the patrimonial point of view, under the rules and principles of civil contractual liability (Article 254, Labour Code), for material damages produced to the employer, by their fault and in connection with their work duties. (Drumea M. C., 2008, p. 152) Given the regulations of Law no. 53/2003, amended and republished in 2011, according to which the employees' patrimonial liability, for material damage caused to employer, is committed under the rules and principles of civil contractual liability, a brief overview of legislation is necessary. Under the Civil Code provisions, the contract is the agreement between two or more persons to constitute or to extinguish between them a legal relation; the closed legal agreements have the force of law between the contracting parties. The contract is characterized by its bilateral nature and by the effect of giving rise to obligations; the concept of the Civil Code, on the role of contract is reflected in two fundamental principles expressed by the autonomy of contractual will and contractual consensus.

\section{Labour law patrimonial liabilities backgrounds}

In Romanian law, the employer is bound, under civil contractual liability regulations to material and moral reparations regarding the employee, if the 
damages occurred within work duties, while the employees is bound to compensate only the material damages. Several authors (Ştefănescu I. T., 2012, p. 773; Gîlcă C., 2013; Ţop D., Mocanu L., Neculaescu S., Gheorghiu G., \& Postolache R., 2010, pp. 242-244) have contended that the patrimonial liability as it is regulated under the Labour Code represents a derived form of the civil liability, its essence being bound the employment contract only. Taking the similar view, other authors (Ticlea Al., 2013, p. 773) have argued that there are cases where, if the damage is caused by the employee and the harmful deed is related to work, tort liability regulations are applied for acts that are under the elements of a crime. Traditionally, the subject is addressed under civil common regulation and labour law provisions, some authors claiming the need (Florian R.Gh., 2013, p. 70) of legislator' revision in terms of establishing an equal treatment for the reparation of the non-patrimonial prejudices caused in labour relation.

Regarding the regional legal approaches, in Bulgaria, recent studies (Mrŭchko V., 2011, p. 106) explore the employers' liabilities depending on the nature of damages, so that the new Labour law regulation prescribes specific cases where the employer is bound by reparation in lump sum, not only for actual causes, but for virtual missed opportunities. The Czech Labour Code reports similar provisions regarding the compensation of actual damages of an employee by the employer, but it reads only the entitlement for material damages, being peculiar and exact in defining the causes and the different natures of the damages.

\section{The patrimonial damages under the employment contract}

The employment contract is a particular contract, submitted to dual regulation: (Drumea M. C., 2008, p. 152)

- the regulation of civil law, which provides its birth and validity;

- the regulation of special law which supplements or even amends the provisions of civil law.

The patrimonial liability (material) is a variant of the civil liability. Its basic elements, such as patrimonial damage, illegal damaging act and the causal relation are the essential elements of civil liability. The civil contractual liability arises from the non-execution of an obligation that the debtor has taken upon him. The contract gives rise to the obligations to be undertaken in good faith: not executing them implies the civil contractual liability, which is nothing but the application of a sanction, desired and acknowledged by the parties upon signing the contract. The proof, the conditions and the effects of not executing the obligation are accessories elements of the civil contractual liability, which separates it from the tort liability.

The essential condition to involve contractual liability is the existence of a contract and its validity, the ultimate goal being the reparation of the patrimonial damage caused to the legal person - to the employer, or to things belonging to him. The contents of the contract should be understood broadly, not only taking into account the terms expressly provided, but also the consequences that "equity, custom or law" give to obligations, after their nature. In the case of an employment contract, in order to operate the patrimonial liability of the guilty persons, two 
cases and the afferent mandatory conditions are given. In the case of material damage produced by an employee, it is required the damage to be the employee's fault and in connection with his work. Also, the employer is obliged to compensate the employee in a situation where he has suffered material damage due to the fault of the employer, while performing work obligations, or in connection with work; the employer who has paid compensation, has the possibility to recover the afferent amount from the employee responsible for producing the damage. Although the article 169, paragraph 1 of the Labour Code provides that any retention of the salary cannot be operated, there are exceptions, one of which is represented by the deductions from the administrators' salary to establish the guarantee fund. The article 169, Labour Code, republished in 2011 says that "no deduction from wages can be operated unless it is provided by law." The Law no. 22/1969 stipulates that "the security fund in cash is retained in monthly instalments of $1 / 10$ of the monthly salary rate or of the average earnings during a month, as appropriate." In relation to the recovery of damages caused by the employee, the article 169 , paragraph 2 of the Labour Code provides that deductions for damage caused to the employer cannot be made unless the employee's debt is falling due, liquid and due, and was recorded as such by a final and irrevocable court decision. According to the article 253, paragraph 1 of the Labour Code, employees respond from the patrimonial point of view, under the rules and principles of contractual liability for damage to property produced to the employer by their fault and in connection with their work. In practice, however, we encounter situations in which the employee recognizes his/ her guilt and agrees to pay damages that are attributable to him/her, in which case the employee's commitment to pay is enough to make deductions from salary, without needing court intervention. Otherwise the Constitutional Court, by decision no. 24/2003, states too that "the provisions of the article 169 , paragraph (2) of the Labour Code refer exclusively to tort liability and not to civil contractual liability; its provisions do not exclude the agreement between parties, but they relate to the situation in which contractual parties do not agree, and when the clear, liquid and due character of the claim must be determined by the court. Within the Decision 660/2011, published in the Official Gazette, the same court stated that according to the idea that the relationship between the employee and the employer must take place only in accordance with the law; the punishment of the employee must meet a series of legal guarantees, including the control of the court.

The text does not exclude the employer's right to resort to the procedure of call for payment, if the character of claim is established as certain, liquid and due. This legislative solution is also supported by the article 8, paragraph 1 of the Convention of International Labour Organization on the employer's salary, no. 95/1949. Of course, assuming that the employee no longer intends to pay good willingly the damage, the employer will need to initiate an action to achieve damage repair and to obtain a permanent and irrevocable court decision, in this regard. Thus, patrimonial liability in the Labour law is based on individual work contract and is grounded on rules and principles of civil contractual liability. (The article 253 of the republished Labour Code) 


\section{The features of the patrimonial liability}

Patrimonial liability in the Labour law is characterized by the following features which individualize it from the civil contractual liability, and which are found both in the liability of the employee and of the employer:

- it is a special liability and it can be resorted to only to the extent when the author of the deed is employed under an individual contract of employment;

- it is a full liability, meaning that the person punished is obliged to repair the effective and present damage as well as the unfulfilled one;

- is a limited liability in terms of forced execution, and it is applied only on a part of the salary (Art 257, paragraph 2, Labour Code amended and republished in 2011);

- it is based on the guilt of the respective person (Drumea M. C., 2008, p. 156), whereas this kind of liability is involved for the damage suffered due to the employer's fault, or for damages produced to the employer by the employees' fault and in connection with their work;

- it is an individual responsibility, excluding, in principle, solidarity. If the damage was caused by several employees, but the proportion in which each contributed to its production cannot be determined, patrimonial liability is established in proportion to his net salary from the date of finding the damage and, when appropriate, also depending on the time actually worked since the last inventory, for those that have the quality of administrators;

- the recovery of caused damage is, usually, done by cash equivalent;

- it is governed by legal rules with imperative character.

\section{Legal provisions that regulate the patrimonial liability}

In order for the patrimonial liability to exist, the following conditions must be satisfied: (Ştefănescu I. T., 2007)

1. The quality of employee, of the person who caused the damage, respectively the person who is part of a typical legal work relation, established on an indefinite or fixed period, or for regular or part-time work.

2. The employee's illegal deed must be committed in connection with his work. To establish patrimonial responsibility, the illicit nature of the deed is analysed in relation to job obligations, arising from individual labour contract, applicable collective labour contract or internal rules. An essential reference point in this respect is the job description. The unit must provide proof of the employees' job tasks whose inadequate performance or failure caused the damage. The employee is personally responsible for his own deed.

3. The damage, meaning the change in the patrimony that is made both by reducing the assets, result of committing an illicit act, or by increasing liabilities. The damage value covers the effective damage and also the unfulfilled benefit.

For the employee to respond from the patrimonial point of view, the damage must meet the following conditions: (Drumea M. C., 2008, p. 155) 
- to be real, that is to be determined on the basis of concrete economic analysis; the employee is not being held to answer for the lost value of the employer's assets, of other causes;

- to be sure, both in terms of its existence and evaluation;

- to be directly caused to the employer. In the event of damage produced indirectly, the employer is responsible as the principal for his official in charge versus the third prejudiced;

- to be material, in the civil law regulation.

Employees are responsible from the patrimonial point of view for material damage produced to the employer by their fault and in connection with their work.

\section{Causes of patrimonial non liability}

There are different cases that do not attract patrimonial liability:

1. The execution of a legal or contractual obligation (provided that the service order is not manifestly unlawful). It is considered, within the specialty literature, that the legal execution of an order, in substance or in appearance, cannot attract the patrimonial liability in cases in which material damage for the employer. This is due to the correlation between the relations of subordination in which the employee is found under the impossibility to refuse the execution of an order by censorship in terms of opportunity. (Drumea M. C., 2008, p. 157)

2. The state of necessity. Whenever the employee commits an act for salvation from an imminent danger of a person, in all its aspects, or goods of valuables or of public interest, and by doing that causes damage, he or her will not be patrimonial liable.

3. Another case is represented by the force majeure and fortuitous event. Whenever the force majeure or unforeseeable circumstances are ascertained, the employees are not liable for created damages.

4. And the last cause that precludes the patrimonial liability is the ordinary risk of a job, i.e. the risk that includes inherent losses in the production process under the limitations of various laws. The unpredictable risk occurs when the damage is minor, acceptable regarding the work position in the case of executing a duty or when the damages are not by the fault of a person, while the ordinary consists of foreseeable losses inherent in the production process, that are under a legal instrument or are negotiated under the individual employment contract or the collective contract.

The procedure of establishing the patrimonial liability is governed by the Labour Code, the rule regarding the recovery of damages is by means of monthly deductions from the debtor's salary. It is not possible to constitute guarantees by the employee by monthly deductions others then strictly provided by law.

According to the Labour Code, Article 257, paragraph 2 "the rates cannot be bigger than one third of the net monthly salary, without exceeding along with other deductions that would have the concerned person the half of that salary."

If the case of the individual contract of employment is terminated before the employee will have compensated the damages for the employer and the concerned 
person finds a job with another employer or becomes a public servant, the salary deductions are made by the new employer or by the new institution or public authority, respectively, based on the writ of execution submitted by the harmed employer to this purpose.

If the person in question is not employed by another employer under an individual employment contract or does not become a civil servant, the damage shall be compensated by his/her property under the Code of Civil Procedure. (Art 258, Labour Code amended and republished in 2011)

\section{Conclusions}

To summarize, we must underline that the patrimonial liability is a form of the contractual civil liability which consists of the employees' obligation to repair caused damage to the employer, by the fault and in relation to their work but, also, the employer's obligation under the rules and the principles of the contractual civil liability, to indemnify the employee in the situation in which he suffered material or moral damage by fault of the employer during work obligations fulfilment or in connection with the job. In order to establish the liability of the employer, it is required to prove the existence of the employer's illegal acts or the material damage suffered by the employee (it is necessary to cover both the actual damage and the loss of the prospective earnings) and the causal link between the act and the damage. The employer's fault is relatively presumed, under the condition of proof that the failure is due to causes that are not attributable to him/ her. (Drumea M. C., 2008, p. 153)

The most common situations where the employee suffers an injury from the employer are those in which he/she is unable to work, the case when the court finds that a measure notified by the employer is unlawful and decides payment of indemnification, if the employer unreasonably, delayed wages, does not grant the annual wholly or partly leave, the employer does not take appropriate security measures and the employee is stolen personal property. But there is a remedy for the employer, after having covered the loss suffered by the employee; he/ she may bring action against the person who is guilty of the damage production.

\section{References}

Drumea, MihneaClaudiu, 2008, Dreptul muncii [Labour law], Constanta: Europolis Publishing House.

Florian, Radu-Gheorghe, 2013, "The issue of liability for non-patrimonial prejudice within the legal labor relations," AGORA International Journal of Juridical Sciences, No. 3 (2013), pp. 60-71.

Gîlcă, Costel, 2013, The Labour Code notes and commentaries, Bucharest: Rosetti International.

Mrŭchko, Vasil, 2011, Labour Law in Bulgaria, Netherlands: Kluwer Law International.

Stefanescu, Ion Traian, 2007, Labour Law Treaty, Bucharest: Wolters Kluwer Publishing House.

Stefanescu, Ion Traian, 2012, Theoretical and practical treatise of Labour law, $2^{\text {nd }}$ edition, added and revised, Bucharest: Universul Juridic. 
The Convention of International Labour Organization on the employer's salary, no. 95/1949.

The Law no. 53/2003, The Labour Code, amended and republished in 2011, published in the Official Gazette no 345, May $18^{\text {th }} 2011$.

Ticlea, Alexandru, 2013, The Labour Code comments, $4^{\text {th }}$ edition, Bucharest: Universul Juridic.

Țop, D., Mocanu, L., Neculaescu, S., Gheorghiu, G., Postolache, R., 2010, „Natural occupational hazards, cause of non-patrimonial liability according to labour law" Proceedings of the International Conference on Risk Management, Assessment and Mitigation, RIMA'10, pp. 242-244. 
